\title{
MIRA SCHENDEL*
}

\section{MIRA SCHENDEL: TATE MODERN GALLERY}

Londres, de 25 de setembro de 2013 a 19 de janeiro de 2014

ANNE WAGNER

TRADUÇÃo dE JOAquim TOledo JR. **

[*] Publicado originalmente no London Review of Books, vol. 35 , out. 2013.

$\left[{ }^{* *}\right]$ Agradeço as sugestões de Samuel Titan Jr.

[1] Nome dado a um grupo informal de artistas britânicos surgido no final da década de 1980, entre eles Damien Hirst e Tracey Emin.
A retrospectiva da artista brasileira Mira Schendel - nascida Myrrha Dagmar Dub, em 1919, na cidade de Zurique, na Suíça, foi criada na Itália, expatriada para a Iugoslávia durante a guerra e, de lá, para o Brasil - na Tate Modern é comovente, difícil, repleta de escritos estranhos e prazer visual imediato. Schendel era uma intelectual inspirada por Wittgenstein e pelo cardeal John Henry Newman (seus dois heróis incompatíveis), e também uma constante inovadora em termos formais. Mas era também uma intelectual que pensava visualmente: ou melhor, que parece ter colocado para si mesma, de forma consciente, o problema de expressar visualmente os extremos de clareza e opacidade que o pensamento pode alcançar.

A mostra de Schendel é parte de uma mudança de foco maior que se deu na Tate Modern no último ano: as exposições individuais passaram a incluir artistas essencialmente novos nos museus de Londres, ou que foram praticamente esquecidos pelos chamados Jovens Artistas Britânicos de Londres ${ }^{1}$ (a única mostra individual de Schendel na Inglaterra foi em 1966). Os 279 trabalhos levados a Bankside compõem a exposição mais completa jamais realizada da artista. As galerias estão cheias, e os objetos que elas contêm, em sua maioria pequenos, são sutis e muitas vezes evasivos; projetam sombras ao mesmo tempo que emanam luz. E nas salas dedicadas a uma única instalação - como em Ondas paradas de probabilidades (1969), composta por inúmeros fios de náilon - o próprio espaço se suaviza e suas bordas se 
esvaem. Há um painel de acrílico pendurado na parede, no qual estão duas passagens do Livro dos Reis 1: 19. Os versos relatam como Elias procurou Deus no vento, no terremoto e no fogo mas só encontrou seu "murmúrio suave" no silêncio que os sucede.

Uma forma possível de se preparar para ver Schendel é imaginar uma artista - sintonizada com o "experimentalismo" dos anos 1960 a partir de uma distância própria, desde São Paulo, da Europa que havia deixado - apaixonada por filosofia e linguística, e por isso interessada em produzir imagens capazes de revelar a linguagem em toda sua estranha fisicalidade. Nos anos 1950 e 1960 havia talvez três dúzias de artistas com esse perfil em três continentes, e a exposição dá motivos para acreditar que Schendel era a mais inventiva entre eles. Sua compreensão ampla dos meios visuais dá os primeiros indícios de suas habilidades. Artista autodidata, trabalhou por alguns anos como designer gráfica. O livro como objeto era parte de sua vida (seu marido, Knut Schendel, era proprietário de uma livraria central do circuito cultural de São Paulo) e ela preservou uma paixão aparentemente inesgotável pelas possibilidades gráficas admitidas por livros e cadernos, tanto quanto desenhos, pinturas, esculturas e instalações. Ao longo dos anos usou óleo, acrílico, aquarela, têmpera, guache, gesso, bastão a óleo, colagem, tela, compensado, papel de arroz, painéis acrílicos, fios de náilon, nanquim, fita de tinta (e a máquina de escrever para aplicá-la), monotipia, decalque - e sem dúvida alguns outros meios que me escaparam. Some-se a isso o seu amor pelas ideias: lia bastante filosofia ocidental e oriental, tinha amigos filósofos e era filha de um judeu tcheco falante de alemão e de uma italiana-alemã que também era judia, mas que batizou sua filha na Igreja Católica. A vida de classe média de Schendel na Europa chegou ao fim em 1938 quando sua ascendência judaica a impediu de continuar o curso de Filosofia na universidade; após dez anos sombrios expatriada na Europa, encontrou refúgio no Brasil, acrescentou o português ao alemão e ao italiano, seus idiomas nativos (também lia inglês), e ali permaneceu pelo resto da vida, fazendo visitas eventuais à Europa para organizar várias exposições importantes. Morreu em 1988, aos 69 anos.

Não há nada de provinciano nesse histórico pessoal. Assim como os Estados Unidos, o Brasil era um lugar ideal 
para assimilar e transformar as realizações da abstração, e a própria substância de sua manipulação das geometrias dominantes - o sabor alternadamente urbano e doméstico que ela lhes confere - mostram como ela incorporou rapidamente aquela herança. Sua abstração é lacônica mas sólida. Suas geometrias preponderantemente cinza e pretas evocam um mundo feito de componentes fundamentais: terra e céu, luz e escuridão, aqui e lá. A certo ponto, surgem insinuações de cidades e edifícios. Esses efeitos são intensamente dinâmicos - me surpreendi pensando em Deus separando a luz das trevas -, mas seu mundo também é estranhamente sem lugar: pós-Éden, pós-queda, esperando um futuro que abriga poucas esperanças.

Para Schendel, a esperança do futuro repousava em um mundo de palavras. Em meados da década de 1960 voltou a trabalhar com recursos gráficos, usando monotipia para imprimir, em papel de arroz finíssimo, desenhos baseados em textos, sobrepondo-os depois em painéis acrílicos, pendurados a poucos centímetros da parede. O resultado é que cada folha se revela, ao mesmo tempo, imagem e texto - ou, em outras palavras, uma superfície graficamente densa de palavras dispersas, algumas plenamente legíveis, outras borradas e quase apagadas. Schendel produziu uma dessas séries em resposta a uma composição de Stockhausen, Canção dos jovens, um marco histórico (a "primeira obra-prima da música eletrônica”, como costuma ser descrita), que combina sons gerados eletronicamente com fragmentos gravados da voz humana. Por volta de 1962 estava disponível em vinil pela Deutsche Grammophon. Schendel escutava esse palimpsesto fantasmagórico em seu ateliê em São Paulo e derivou dele um conjunto de palavras-chave, uma espécie de canto poliglota, cada uma interpretada em rabiscos que variam imensamente em clareza e estilo. Esses desenhos parecem gráficos compostos de maneira inteiramente nova: querem ser ouvidos. "Fogo", por exemplo, se torna "FEUER fuoco fire FEU feuer FUOCO", a simples repetição insistindo no tema da composição de Stockhausen, a salvação por Deus de três jovens judeus devotos da incineração no forno de Nabucodonosor. Freud analisa um sonho no qual um pai enlutado imagina seu filho morto lhe perguntando: "Pai, não vê que estou em chamas?". O trabalho de Schendel, junto 
com o de Stockhausen, trouxe a questão insuportável para a arte do pós-guerra.

Em meados da década de 1960, Schendel passou a torcer folhas de papel de arroz, transformando-as em cordas ou fitas densamente comprimidas que amarrava ou enlaçava, criando correntes ou tecidos frouxos que, quando empilhados ou suspensos, se assemelhavam a redes improvisadas. Alguns anos mais tarde, em seu loft em Bowery, Eva Hesse trabalharia com sacolas de rede e, então, um pouco mais tarde ainda, com meadas de nós de corda. E na mesma época em que Hesse pendurou painéis de látex translúcidos em branco sob o título Aught, com seus ecos de "ought" e "naught", Schendel alinhava conjuntos amolecidos do mesmo papel macio com o qual adorava trabalhar, formando fileiras que sua filha Ada batizou de "Trenzinhos". O nome pegou, assim como "Droguinhas", o apelido de Ada para as redes de nós da mãe. Os trabalhos "pequenos" de Schendel são fisicamente delicados, no entanto, a presença inesperada que ela extrai desses papéis ultrafinos, com sua brancura e ausência intrínsecas, é de tirar o fôlego. Ninguém viaja nesses trens e ninguém é colhido por essas redes - com exceção do espectador, e, inevitavelmente, a própria artista. "Pequenos nadas", talvez, mas ainda assim capazes de invocar o enorme nada, fruto da experiência da destruição total da vida, que assombrou o pós-guerra.

O objetivo de Schendel, no entanto, era levar o espectador para além do nada, e a mostra na Tate Modern sugere que ela o atingiu. $O$ percurso passa pela mais ambiciosa de suas instalações, que ela projetou para o pavilhão brasileiro da Bienal de Veneza de 1968. Esse trabalho agrupa doze Objetos gráficos, "imagens" de acrílico penduradas, cada uma com não mais do que um metro quadrado, nas quais duas camadas recobrem uma folha de papel de arroz saturada de letras escritas à mão e sinais que se assemelham a letras. Decalques de letras germinam entre elas, sua nitidez de tipo sem serifa revelando seu uso característico por arquitetos e designers gráficos, destacando-se entre signos e sombras e dando forma a seus fluxos e convergências.

Esses painéis foram concebidos para ser vistos à luz do dia, como a instalação na Tate Modern permite maravilhosamente. $O$ resultado é a experiência de ler suas não mensagens
[2] Respectivamente, "coisa alguma", "deve" e "coisa nenhuma". [N.T.] 
através e no interior de cada uma, ao mesmo tempo que é possível perceber cada presença flutuante como algo separável. O efeito sobrepõe sombra a sombra, enquanto o exterior é luz. Em seu diário, Schendel descreveu que sua intenção era tentar "mostrar que o reverso da transparência está diante de nós, e que 'o outro mundo' é esse mundo". Uma ambição caracteristicamente singela e enorme, que, vez após vez, seu trabalho realiza.

ANNe Wagner é professora emérita de História da Arte na Universidade da Califórnia em Berkeley. 